Introduction to Statistics for

Geographers and Earth Scientists 
Other Macmillan titles of related interest

R. Till, Statistical Methods for Earth Scientists

R. B. G. Williams, Intermediate Statistics for Geographers and Earth Scientists (companion volume) 


\title{
Introduction to Statistics for Geographers and Earth Scientists
}

\author{
R. B. G. Williams \\ University of Sussex \\ Brighton
}

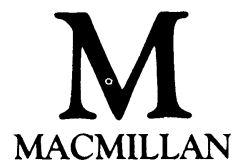


다. R. B. G. Williams 1984

All rights reserved. No part of this publication may be reproduced or transmitted, in any form or by any means, without permission.

First published 1984 by Higher and Further Education Division MACMILLAN PUBLISHERS LTD

London and Basingstoke Companies and representatives throughout the world

British Library Cataloguing in Publication Data

Williams, R.B.G.

Introduction to statistics for geographers and earth scientists.

1. Geography-Statistical methods

I. Title

519.5'02491 G70.3 


\section{Contents}

Preface vi vi

Acknowledgements vii

1. The Aims of Statistics 1

2. Types of Numerical Data 4

3. Populations and Samples 9

4. Probability and Randomness 25

5. Frequency Distributions 38

6. Measures of Centra1 Tendency 51

7. Measures of Dispersion and Skewness 61

8. The Binomial and Poișson Distributions 72

9. The Normal and Log-Normal Distributions 85

10. Hypothesis Testing: An Introduction 115

11. One-Sample Tests Based on $Z$ and $t \quad 123$

12. Interval Estimation Based on $Z$ and $t \quad 146$

13. Paired-Sample Tests Based on $t$ and $w \quad 151$

14. Two-Sample Tests Based on F, $t$ and $U$ 164

15. Chi-Square Tests 189

16. *The Binomial Test and Lilliefors' Test 218

17. The Product-Moment Coefficient of Correlation 226

18. The Interpretation of Correlation Coefficients 258

19. Linear Regression 279

$\begin{array}{lll}\text { 20. Confidence Limits and Significance Tests for Sample } & \\ \text { Regression Lines } & \end{array}$

Statistical Tables 324

References $\quad 336$

Further Reading $\quad 344$

Index $\quad 345$ 


\section{Preface}

This book aims to provide a comprehensive introduction to the subject of Statistics. It describes a wide range of elementary techniques, including those most commonly selected by research workers or taught in undergraduate courses at Universities and Polytechnics. The value of each technique is discussed, and attention is drawn to the pitfalls that must be avoided if the technique is to be correctly applied.

All the techniques are illustrated by carefully worked examples utilising real data. The examples are drawn from geography, planning and the earth sciences, but readers with backgrounds in other disciplines should not find them difficult to understand. All the calculations can be carried out using pencil and paper or using a simple pocket calculator, and only an elementary knowledge of mathematics is assumed.

The manuscript for this book has been used as a photostated text by geography students at the University of Sussex taking undergraduate statistics courses or engaged in postgraduate research. The manuscript has been revised and extended as a result of many useful suggestions from colleagues and students. I am particularly indebted to Dr. D.C. Funne11, Dr. T. Browne and Professor K.J. Tinkler for helping with sections of the text where their knowledge is more extensive than mine. I should also like to express my gratitude to Susan Rowland for undertaking the drawing of the diagrams. Needless to say I am responsible for any errors that remain either in the text or the diagrams, and I will be grateful to readers if they will draw them to my attention.

Sections of the text marked with an * may be skimmed over on first reading or omitted altogether if time is short. Although the theoretical background of each technique is explained before a worked example is given, some readers may prefer to study the example first and examine the theoretical background only when they have understood how the technique is applied.

More advanced topics in statistics, especially in regression and correlation, are examined in "Intermediate Statistics for Geographers and Earth Scientists", the companion volume to the present book. This volume contains a detailed discussion of the logic of significance testing, and examines the various ways in which statistical techniques have been used and misused in scientific research.

Computer program listings have not been included in the text because of space limitations, but it is hoped shortly to issue software cassettes with programs in BASIC that will run on the BBC Mode1 B microcomputer.

University of Sussex

December 1983 


\section{Acknowledgements}

The author and publishers wish to thank the following who have kindly given permission for the use of copyright material:

American Journal of Science for an adapted diagram from article by Arthur N. Strahler in Volume 248; October 1950.

Cambridge University Press for two adapted diagrams from The Lognormal Distribution (1969), by J. Aitchison and J.A.C. Brown.

Holden-Day Inc. for tables adapted from Nonparametrics (1975) by E.H. Lehmann

The Institute of British Geographers for adapted diagrams from article 'The geomorphological importance of jointing in the Dartmoor granite' by A.J. W. Gerrard, No. 7, June 1974; from article 'The redistribution of parliamentary seats in the United Kingdom: themes and opinions' by Gwyn Rowley in Area, Volume 7, No. 1, 1975; from article 'Suspended sediment delivery rates and the solute concentration of stream discharge in two Welsh catchments' by N.C. Oxley; and from article 'The geometry of shore platforms in England and Wales' by A.S. Trenhaile, No. 62, July 1974.

The Journal of Geology for a diagram adapted from article 'Statistical analysis in geomorphic research' by A.N. Strahler in Volume $62,1-25,1954$.

Longman Group Limited for a table adapted from Statistical Tables for Biological, Agricultural and Medical Research, 1974, 6th Edition by Fisher and Yates.

Isamu Matsui for map and grid adapted from article in Japanese Journal of Geology and Geography, Volume 9, No. 3-4.

McGraw-Hill Book Company for tables adapted from Schaum's Out line of Theory and Problems of Statistics by Murray R. Spiegel, and Introduction to Statistical Analysis by Wilfred J. Dixon and Frank J. Massey, Jr.

The Royal Geographical Society for figures from 'Aspects of the morphometry of a "poly-cyclic" drainage basin' by Professor R.J. Chorley, in The Geographical Journal, Volume 124, 1958. 
Universe Books for an adapted graph from The Limits of Growth: $A$ report for The Club of Rome's Project on the Predicament of Mankind (Potomac Associates, 1972) by Donella H. Meadows, Dennis L. Meadows, Jфrgen Randers, William W. Behrens III.

John Wiley \& Sons Inc. for a table adapted from Practical Nonparametric Statistics (1971) by W.J. Conover.

Zambia Geographical Association for two figures adapted from The Climate of Zambia (Occasional Study No. 7) by Peter Hutchinson.

We also thank F.E. Croxton for permission to produce Table B - an adapted version of tables that were originally included in Applied General Statistics by F.E. Croxton, D.J. Cowden and S. Klein (Pitman, 3rd edn).

Every effort has been made to trace all the copyright holders but if any have been inadvertently overlooked the publishers will be pleased to make the necessary arrangement at the first opportunity. 